Annales Missiologici Posnanienses t. 19 (2014), s. 91-105

DOI: $10.14746 / \mathrm{amp} .2014 .19 .4$

\author{
ALBRECHT CLASSEN \\ Department of German Studies, University of Arizona,Tuscon
}

\title{
Jesuit Missionaries Building a Global Network. Eighteenth-Century Exploration of the World in the Name of God - A Story of Disjointed Memory
}

Globalization can be impressively illustrated through a critical examination of the Jesuits as they existed until the late eighteenth century. ${ }^{1}$ I want to describe a particular aspect of the early history of the region today identified as Northern Mexico and Southern Arizona, commonly called 'Sonora,' before I turn my attention to a discussion of a publication reflecting the universal outreach by the Jesuits.

From a European perspective, that territory in northern Mexico was as far away and outside of the cultural center of the western world as possible, at least for that time. Sonora was a fairly barren land; it could not pride itself on a significant cultural history, and it was not yet recognized as an important source of minerals and ores. Europeans shied away from that part of the world for many good reasons, but Sonora was populated, after all, by numerous different native tribes. These became the target of intensive Jesuit missionary activities beginning in the late seventeenth century particularly after the first missionary, Eusebio Kino (1645-1711), arrived in $1687 .^{2}$

${ }^{1}$ See, for instance, D. Mitchell, The Jesuits: A History, London 1980; J. Lacouture, Jesuits: A Multibiography, Washington, DC 1995; D. Letson, M. Higgins, The Jesuit Mystique, Toronto 1995; J.F. Conwell, SJ, Impelling Spirit: Revisiting a Founding Experience: 1539. Ignatius of Loyola and His Companions, Chicago 1997; see also the contributions to Ignatianisch: Eigenart und Methode der Gesellschaft Jesu, ed. M. Sievernich, SJ, G. Switek, SJ, Freiburg i.Br.-Basel-Vienna 1990, and to The Mercurian Project: Forming Jesuit Culture 1573-1580, ed. Th.M. McCoog, SJ, [Biblioteca Instituti Historici Societatis Jesu, 55], St. Louis, MO, and Rome-Prati 2004. This list could easily be expanded many-fold.

${ }^{2}$ Ch.W. Polzer, SJ, Kino: A Legacy. His Life, His Works, His Missions, His Monuments, Tucson, AZ 1998. 
Despite the loneliness and hardship in their lives, many Jesuit missionaries ventured far into the most northern part of Mexico and entered deeply into the Sonoran Desert, at least to a point both then and until today called 'Casa Grande,' halfway between the modern cities of Tucson and Phoenix, Arizona. The world beyond remained unknown and was thinly populated by Apaches, among other tribes, who prevented the missionaries from extending their network, conversion work, teachings, and preaching, and were commonly identified by their European opponents as ferocious and dangerous. This cultural and military clash continued into the late nineteenth century. ${ }^{3}$

Founded by Ignatius of Loyola in 1540, the Jesuits quickly expanded all over Europe and then moved onto the global stage, sending out missionaries into every corner of our world, except for Australia which was not discovered by Europeans until 1603 - the first Jesuits arrived there in $1848 .{ }^{4}$ In every respect, this order represented a truly global organization, with its center in Rome, whence orders and charges went out all over the world, maintaining contact with countless missions that were all subordinated in a quasi military fashion. At the same time, thousands of Jesuit missionaries sent letters, reports, treatises, and other documents from all over the world to Rome, to their individual superiors, and at times also to their families back home. Almost all of these missionaries hailed from highly advanced educational institutions and had hence received some of the best intellectual training in Europe available in the eighteenth century. The Jesuits embraced the basic principles originally developed by Ignatius - teaching, preaching, and missionizing - and these principles became the foundation for their successful global outreach and network.

Of course, they were not the first Christians and not the first missionaries in North America; in fact, the Franciscans and the Dominicans had arrived well before they, ${ }^{5}$ but the Jesuits pursued a different methodology in reaching the people. They realized the great need to work closely with the local people and to learn the languages and cultures in order to influence and teach them. This does not mean that they arrived without the usual Eurocentric ideology as part of their baggage, but they always made great efforts to acquire the necessary linguistic skills in order to work. ${ }^{6}$

${ }^{3}$ D.E. Worcester, The Apaches: Eagles of the Southwest, [Civilization of the American Indian Series, 149], Norman, OK 1979; J.L. Haley, Apaches: A History and Culture Portrait, Norman, OK 1997; J. Ortega Urquidi, Apaches del Desierto, Mexico City 2011.

$4 \mathrm{http}: / /$ www.jesuit.org.au/files/docs/our-community/our-story/the-history-of-the-jesuits-in-australia.pdf [online 20.10.2014].

5 http://epicworldhistory.blogspot.com/2012/06/franciscans-in-americas.html [online 20.10.2014].

${ }^{6}$ R. Haub, Die Geschichte der Jesuiten, Darmstadt 2007, p. 72. 
While they tried to win Protestant Europe back to the papacy, the Jesuits experienced successes in South and Central America, particularly in Paraguay, where they struggled against many of the Spanish land- and mine owners. Little wonder that these and many other reasons merged into general opposition to the Jesuits. ${ }^{7}$

Although the missionary Padre Eusebio Kino reached Sonora in 1687, and then was followed by many waves of succeeding missionaries mostly from the German province of Jesuits, the Jesuits were banned from the Americas in 1767 , and then forbidden globally in 1773 . They were readmitted in 1814, and since then they worked to recover their global network. ${ }^{8}$

Researchers have been deeply fascinated by the history of the Jesuits while outsiders have mostly ignored them, because they operated primarily behind the scenes and often used their schools and universities to achieve their religious goals. Still, they worked not only as teachers, missionaries, and priests, but they also pursued farming and commerce: buying and selling in order to support their preaching efforts. In Sonora, above all, they operated many missions, which were the centers of agricultural activities. They provided schooling for the young, established basic hospitals, offered shelter from hostile tribes, especially the Apaches and Seris, made available job training (in modern parlance) for young adults, and they served as patrons of the arts, as administrators, and as judges. ${ }^{9}$

Their written documents are extensive and a large percentage is still awaiting critical analysis. These extensive archives, in a number of major locations, confirm what this article wants to bring to light, that is, the Jesuit global perspective. They strove to interact with the local people, the local climate, the fauna, and the flora, and, above all, to set up new organizations in the new world, importing European concepts to new cultures. ${ }^{10}$

This obviously appealed strongly to young people in Europe, especially in German- and Czech-speaking lands where the constant reports about the mis-

${ }^{7}$ U. Paintner, 'Des Papsts neue Creatur': Antijesuitische Publizistik im deutschsprachigen Raum (1555-1618), [Chloe, Beihefte zum Daphnis, 44], Amsterdam-New York 2011.

${ }^{8}$ A. Classen, Early History of the Southwest Through the Eyes of German-Speaking Jesuit Missionaries: A Transcultural Experience in the Eighteenth Century, Lanham, Boulder, et al.: Lexington Books, 2013.

${ }^{9}$ A. Classen, The Letters of the Swiss Jesuit Missionary Philipp Segesser (1689-1762): An Eyewitness to the Settlement of Eighteenth-Century Sonora (Pimeria Alta), ed. and trans. A. Classen, [Arizona Center for Medieval and Renaissance Studies, Occasional Series, 5], Tempe 2012.

${ }^{10}$ H. Schmuck, Philipp Segesser, SJ (1689-1762): Exemplarische Biographie eines mitteleuropäischen Missionars in Nueva España, [Mainzer Studien zur Neueren Geschichte 11], Frankfurt a. M. 2004; El saber de los jesuitas: historias naturales y el Nuevo Mundo, ed. L. Millones Figueroa, D. Ledezma, [Textos y estudios coloniales y de la independencia, 12], Frankfurt a. M.-Madrid 2005; R.A. Schroth, SJ, The American Jesuits: A History, New York-London 2007. 
sionaries all over the world reached a large audience hungry for news about the rest of the world. Between 1558 and 1772, just one year before the Jesuits were suppressed, the Jesuit general government in Rome received more than 15,000 letters requesting them to grant permission to go into one of the missions. ${ }^{11}$ The accounts by the first missionary, Francis Xavier (1506-1551), and others from far away excited European readers, but it took until the early eighteenth century before the Spanish Crown also allowed missionaries from north of the Alps to go to the New World, probably because they had run out of southern candidates. For a long time, too, Lutheran as well as Catholic countries prevented scores of highly passionate German missionaries to travel to exotic lands, but the early eighteenth century enforced a change because the Church ran out of Spanish volunteers to serve in the rough and dangerous terrain in northern Mexico. ${ }^{12}$

It would be unfair to characterize those young men as purely driven by curiosity or as religious tourists. Religious devotion and a deep commitment to preach, convert, and baptize the heathens were their primary motivations. This did not mean that they were blind to the natural environment, to foreign cultures, and to different languages. Moreover, many of these missionaries were experts in a variety of scientific fields, such as astronomy, cartography, medicine, pharmacy, mathematics, etc., as the resulting reports, maps, and treatises about the conditions abroad confirm. The first task, however, especially in the New World, was to establish an efficient agriculture and to settle the parish, and then to implement European norms of behavior, decency (usually clothing), monogamy, craftsmanship, artistic activities, and learning. ${ }^{13}$ Teaching, preaching, conversion, and baptism would follow. The Jesuits were, mostly involuntarily, spearheads of Spanish and Portuguese colonization, but they were less malleable instruments in the hands of the secular authorities than more obedient to their own authorities.

No mission existed by itself. It always consisted of a larger network of missions, which were subordinate to a bishop and a Jesuit superior, and everyone higher up reported to the authorities in Mexico City and then to Rome. As a result, we have a huge corpus of relevant texts which make it possible to

${ }^{11}$ R. Haub, Die Geschichte der Jesuiten, op.cit., p. 72.

${ }^{12}$ A. Classen, España a través del prisma alemán: perspectivas del Medievo y la primera Modernidad e investigaciones imagológicas, in: Viajes y viajeros entre ficción y realitad: AlemaniaEspaña, ed. B. Raposo Fernández, I. García Wistädt, Valencia 2009, p. 41-59.

${ }^{13}$ B. Hausberger, Jesuiten aus Mitteleuropa im kolonialen Mexiko: Eine bio-bibliographie, Vienna-Munich 1995, p. 9-13; for the motivation of the Jesuit missionaries from north of the Alps, see p. 42-46; id., Für Gott und König: die Mission der Jesuiten im kolonialen Mexiko, [Studien zur Geschichte und Kultur der iberischen und iberoamerikanischen Länder, 6], Vienna-Munich 2000; D.T. Reff, Plagues, Priests, and Demons: Sacred Narratives and the Rise of Christianity in the Old World and the New, Cambridge-New York 2005. 
understand much of the internal structure of the Jesuit Order both in Europe and in the New World. This corpus, in turn, sheds important light on the global organization and demonstrates how closely the hundreds of outposts were connected with the center of the Order. Even though Sonora, or the Pimería Alta, as that semi-arid was locally known, was far away from the main arteries of global trade and cultural activities, the Jesuit missionaries created nodes to expand the network. Their reports often dealt with official business in the missions, but there are numerous accounts, such as letters, that reflected their personal experiences and emotions, too.

In recent years, much new research has focused on those German-speaking Jesuit missionaries who were prolific writers, highly energetic, and wellorganized administrators, and also excellent scientists in different fields. ${ }^{14}$ Moreover, musicologists have realized the great contributions by the Jesuits to the recording of and development of music in their missions. Mostly, these missionaries worked hard to introduce European music, primarily for church services, but they also reflected on the music produced by indigenous peoples. Since the Jesuits pursued a strongly Eurocentric perspective, they harbored mostly negative sentiments about native cultures; nevertheless, we can still use some of their writings to gain some insights into the ancient practices which they encountered. ${ }^{15}$

Even though the Jesuit missionaries mainly originated from the so-called Southern German province of Jesuits, they hailed from many different places in northern Europe, too. Maximilian Amarell (1651-1696) originated from Vana, Bohemia; Johann Jakob Baegert (1717-1772) was born in Schlettstadt, Alsace; Johann Anton Balthasar (1697-1763) hailed from Lucerne, Switzerland; Michael Bauer (1712-1774) was born in Mainz; Anton Maria Bentz (1716-1776) came from Dillingen/Bavaria; Johann Berens was born in Koblenz in 1709; Johann Xaver Bischoff (1710-1761) was born in Glatz/ /Kłodzko; Joseph Martin Bonani (1685-1752) was born in Lanza, Trento; Karl Boranga (1640-1684) was born in Vienna; Simon Boruhradský (1650-1697) was born in Polan/Polnâ in Moravia; Benno Ducrue (1721-1779) came from Munich; Wenzel Eymer (1661-1709) originated from Melnik/Mělník in Bohemia; Georg Fraidenegg (1727-1775) was born in Castle Pichelhofen in Styria; Joseph Gasteiger (1702-1754) came from Leoben in Styria; Joseph Göbel (1714-1778) was born in Neisse/Nysa, in Silesia; Johann Baptist Gratzhofer (1690-1733) was born in Bleiburg in Corinthia; Johann Baptist Haller (1652-

${ }^{14}$ A. Classen, Early History, op.cit. (see note 16); idem, The Letters of the Swiss Jesuit Missionary, op.cit. (see note 17).

${ }^{15}$ See the contributions to Jesuitische Musik- und Theaterpraxis im kolonialen Amerika, ed. Ch. Storch (forthcoming). 
-1718) originated from Gemona del Friuli, in Friuli, northern Italy; Franz Hlava (1725-1768) was born in Prague; Daniel Januske (1661-1724) originated from Breslau/Wrocław; Adam Kall (1657-1702) came from Eger/Cheb, Bohemia; Marcus Antonius Kappsu (1567-1717) was born in Laibach/Ljubljana, Slovenia; Eusebio Kino (1645-1711) came from Segno near Trento; Joseph Kroff (1700-1734) was born in Tischenreuth in Bavaria; Bernhard Middendorff (1723-1782) came from Vechta in Lower Saxony; Johann Nentuig (1713-1768) was born in Glatz/Kłodzko, Silesia; Joseph Neumann (1648-1732) was born in Brussels; Joseph Och (1725-1773) came from Würzburg; Alexander Rapicani (1702-1768) originated from Bremen; Franz Xaver Reittenberger (1707-1767) was born in Prague; etc. ${ }^{16}$

This short selection clearly demonstrates that even this rather forlorn corner of the vast Jesuit network that spanned the entire globe attracted missionaries from all over northern Europe, not mentioning those from Spain, Portugal, France, and Italy, of course. We cannot claim that these missionaries arrived in Sonora simply out of personal motives; their superiors assigned them their duties and directed them to make their way to their various posts in the vast expanse of the Sonoran desert. The arid and harsh climate represented a huge challenge in the eighteenth century, although at that time much more water must have been available, with the local rivers still running year-long. Today, they are all dry washes and fill up only during strong downpours and thunderstorms. The Jesuits often faced hostile conditions and had to work hard to establish peaceful relationships with the various tribes. These were mostly nomads and did not know much of agriculture.

Central and South America were quite different. We have to realize that Jesuit mission history consists of countless individual conditions, which could make it almost impossible to summarize, if we did not view it in the light of early modern globalization. Many European and American historians continue to ignore the enormous impact which the Jesuits had everywhere, unless they focus on that Order specifically. ${ }^{17}$ In fact, we could call the Jesuit Order one of the first global organizations, following the Catholic Church, naturally, and their own precursors, the Franciscans and the Dominicans.

If we want to understand the global political, economic, religious, cultural, and military conditions in the seventeenth and eighteenth centuries, then an examination of what the Jesuits had to say about themselves and how their contemporaries responded to them will prove to be meaningful and far-reach-

${ }^{16}$ See B. Hausberger, Jesuiten aus Mitteleuropa, op.cit. (see note 21). He notes, also based on older research, the surprisingly large percentage of missionaries from Bohemia, now the modernday Czech Republic, p. 26-33.

${ }^{17}$ See, for instance, the characteristic case of R. Stark, How the West Won: The Neglected Story of the Triumph of Modernity, Wilmington, DE 2014. 
ing. Most missionaries assumed rather lonely posts and had to work in alienating social and natural environments, forcing them to accept challenging living conditions. Some were martyred (e.g., Heinrich Ruhen, 1751), many suffered from loneliness and sickness, and all of them, despite their profound dedication and passion for their religious cause, accepted that they would never return home. Of course, the major exception was that the American Jesuits were then expelled in 1767, forced to travel to Cuba, from there to Spain, and only years later to their home towns all over Europe, but this is not the topic of our paper.

In order to grasp more in detail what the global approach by the Jesuits might have meant and how many of the missionaries perceived the foreign, that is, in our context, the New World, one of the most comprehensive sources available (but never discussed at great length or translated) with an in-depth insight into the broad range of Jesuit activities all over the world and of their subsequent texts is, Joseph Stöcklein's Der Neue Welt-Bott mit allerhand Nachrichten deren Missionarien Soc.[ietatis] Iesu ... . ${ }^{18}$

Stöcklein collected a huge corpus of letters written by Jesuits all over the world and sent to Rome. He also translated them, if they had not been composed in German, into that language. This Welt-Bott (World Messenger), as it was often cited, can be identified as one of the most comprehensive collections of Jesuit writings on a global level and allows us to gain perspective into the highly energetic, well-organized missionary activities centrally controlled by the Society of Jesus. The frontispiece to this mighty volume clearly illustrates the global approach by the Jesuits. It shows a floating messenger pulling a globe behind him. The globe shows us Europe, the Americas, northern Africa and part of Asia. The image itself shows us a harbor with a tall ship, its banner flying the Jesuit monogram. The caption quotes Luke 13:29, "They will arrive from the Orient and the Occident, from midday and midnight."

${ }^{18}$ The full title: Allerhand So Lehr-als Geist-reiche Brief / Schrifften und Reis-Beschreibungen / Welche von denen Missionariis der Gesellschafft Jesu Aus Beyden Indien / und andern Über Meer gelegenen Laendern / Seit An. 1642. biß auf das Jahr 1726 in Europa angelangt seynd. Jetzt zum erstenmal Theils aus Handschrifftichen Urkunden / theils aus denen Französischen Lettres Edifiantes verteutscht und zusammen getragen, von Joseph Stöcklein (Fortgesetzt von Petrus Probst und Franciscus Keller), Augsburg-Graz: In Verlag Philips / Martins / und Joh. Veith seel. Erben, 1725-1758. [All Kinds of Instructive and Intelligent Letters, Tracts, and Travelogues Which Had Been Written and sent to Europe by Missionaries of the Society of Jesus in Both Indies and in Other Countries Situated Overseas from 1642 to 1726; Now for the First Time Translated and Compiled to Some Extent From Handwritten Documents, to Another Extent from the French Lettres Edifiantes]. Curiously, the first part was printed in 1726, at the same time as the third. I was fortunate enough to have available an original copy of Stöcklein's work in the Special Collections, University of Arizona Library, Tucson, Oversize BV 2290.A27.1642. Large sections of my discussion of Stöcklein's works are from my monograph, Early History of the Southwest. I revisited the original work and refashioned my original text in light of the particular focus pursued here. 
Stöcklein's intention was two-fold: on the one hand to demonstrate the true accomplishments of his Order to the world, and on the other, equally importantly, to fend off the growing criticism of and hostility against Jesuits wherever they worked as missionaries, as preachers, as teachers, and as instructors. ${ }^{19}$ Moreover, as we can easily recognize both in the prologue and in the texts, Stöcklein aimed at a broader audience, since he translated all of the texts into the vernacular, i.e., German, and promised much excitement for his readers since the letters had been sent from the widest range possible of exotic places where Jesuit missionaries worked. Anyone possibly interested in traveling to distant lands was hence invited to join the Society of Jesus, because that organization offered positions as missionaries even in the remotest places imaginable. He also claimed that this Jesuit literature offers particularly intriguing perspectives since: "an inquisitive reader can, without taking any step, sitting at home, simply reading of those accounts, wander throughout the entire world and is thus enabled to acquire a nearly complete understanding of the entire globe without facing any dangers, costs, or efforts." 20

Whereas missionaries, as expected, would relate all the relevant aspects of their activities as priests, confessors, and the like, they would also use the opportunity offered in their letters and reports, "to provide us with all kinds of very useful information about nearly all sciences and arts." ${ }^{21}$ In other words, the texts written by the Jesuits allow us to examine more carefully a variety of discourses, especially about conversion, preaching, the scientific exploration of the New World in northern Mexico, and also autobiographical statements,

${ }^{19}$ Not surprisingly, and as a confirmation of Anton Huonder's observation (Deutsche Jesuitenmissionäre des 17. und 18. Jahrhunderts: Ein Beitrag zur Missionsgeschichte und zur deutschen Biographie, [Ergänzungshefte zu den "Stimmen aus Maria-Laach," 74], Freiburg i. Br. 1899), Stöcklein is not even mentioned in the most comprehensive biographical reference work, Allgemeine deutsche Biographie (in print and online at: http://www.deutsche-biographie.de/index.html). And B. Hausberger, Jesuiten aus Mitteleuropa, op.cit. (see note 21), p. 17-18, names him only in passing. B. Duhr, SJ, Deutsche Auslandssehnsucht im 18. Jahrhundert: Aus der überseeischen Missionsarbeit deutscher Jesuiten [Schriften des Deutschen Auslands-Instituts. A: Kulturhistorische Reihe, 20], Stuttgart 1928, p. 45-49, offers at least an analysis of the Welt-Bott. Stöcklein himself does not tell us anything about himself in biographical terms. Duhr provides the following biographical data: Stöcklein was born on July 30, 1676 in Oettingen and joined the Jesuits in 1700 in Vienna. For ten years he served as a military chaplain in Hungary and was highly sought after as a preacher. $\mathrm{He}$ knew French, Greek, and Hebrew. Later, he was the head of the Jesuit library in Graz for six years, and for three years the head-editor of the Welt-Bott. This massive auvre, however, was completed long after Stöcklein's death (on Dec. 28, 1733) in 1761.

20 "Ein neugieriger Leser / ohne einen Schritt zu thuen / zu Hauß sitzend mit blosser Lesung dergleichen Schrifften die gantze Welt durchwandern / hiedurch aber ihm selbst eine bey nahe vollständige Erkantnuß des gantzen Erd= Creyß ohne Gefahr / Unkösten oder Mühe erwerben kan.” Ibid.

21 "uns über fast alle Wissenschafften und Kuensten mancherley sehr nutzliche Kundschafften zu ertheilen." Ibid., $1 \mathrm{v}$. 
not to forget anthropological aspects, biology, geology, climatology, astronomy, politics, economics, and history on both a global and a local level.

The entire volume is divided into categories according to the provenance of the individual letters, beginning with those having been sent from the Mariana Islands, then from the Philippines, China, and South-America, continuing with letters from North America, and concluding with letters from India. Although Stöcklein declares in the prologue that he translated these letters, it seems highly unlikely that he did so with letters written by German speakers to their relatives back in Germany, such as Adam Gerstl's letter to his father in Vorderberg in Styria from July 14, 1681 (part 1, no. 31, 90-102). ${ }^{22}$

Stöcklein also included a number of maps, whereas illustrations, with very few exceptions were not incorporated because they would have made the volume too expensive. If we needed any proof of the global perspective pursued by Stöcklein and the entire Order of the Jesuits, this massive volume provides convincing evidence, since the reports come from every corner of the world. Finally, the Index rerum memorabilium (Index of memorable items) at the end indicates how much Söcklein was interested in using these letters to inform his audience about the widest possible range of topics concerning cities, landscapes, animals, plants, people, customs, and the like all over the globe as observed and discussed by the many different Jesuit authors who submitted detailed accounts about their specific regions.

Stöcklein edited the texts as he translated a large part of them from French and Latin into German, and offered brief summaries of the major points addressed in each, such as in the case of the letter by the German-Slovenian Marcus Antonius Kappus to his brother Johann von Kappus in Krain, dated June 20, 1699 (volume 2, no. 56, 86-88). ${ }^{23}$

Full of admiration, he outlined how much the missionaries had crossed rivers and oceans, had brought Christianity everywhere and had learned even the most exotic languages in order to preach to the heathens. Stöcklein identified them collectively as true martyrs and as honorable servants of God who deserved the highest respect, if not here on earth, then in eternity. His work, he hoped, would serve to make the missionaries' accomplishments known in Germany, and would inspire many there to join the Society of Jesus, and then become missionaries in their turn (XX 1r).

${ }^{22}$ B. Hausberger, Jesuiten aus Mitteleuropa, op.cit. (see note 21), p. 148-49, also refers to this letter and identifies it as German in its original, though the original seems to be lost.

${ }^{23}$ A. Classen, The Scientific, Anthropological, Geological, and Geographic Exploration of Northern Mexico by Eighteenth-Century German Jesuit Missionaries: A Religious and Scientific Network of Multilingual Writers. With a Focus on Johann Nentuig and Marcus Antonius Kappus, "Mitteilungen des Instituts für Österreichische Geschichtsforschung" 122.1 (2014), p. 40-61. 
Stöcklein was optimistic that his account might also appeal to those armchair travelers who did not want to undertake difficult and dangerous journeys on behalf of the Society of Jesus and who could, simply by reading, get to know the entire world and thus partake indirectly in the missionary work. While he pursued a religious perspective in support of the Jesuits, he was also aware of the general appeal which any travelogue could exert for the general reader (XX 1r). In this regard his Welt-Bott fulfilled a number of important functions, providing members of the Society of Jesus with eye-witness accounts of what their confreres had accomplished globally, offering insights into their countless suffering and martyrdom, and demonstrating to the general reader the great idealism inspiring the Jesuits. In other words, the Welt-Bott was both an extensive travelogue and a propaganda tool, a compilation of fascinating and deeply appealing accounts about missionary work abroad and a detailed documentary of the types of works carried out by the Jesuit missionaries globally.

Shifting the argument completely away from the religious perspective, the author insists on the value of those letters as scientific documents since they contained so much valuable information about different cultures, practices, methods, and strategies, whether pertaining to theology, law, medicine, philosophy, mathematics, geography, or ethics. The Christian missionaries, for instance, could gain a valuable lesson from Hindu ascetics, who could teach many European preachers (XX 2v). By contrast, as Stöcklein confirms, Islam represented a tough challenge, which made the focus on America, where there was no other monotheistic religion comparable to Islam, understandable, especially for the Jesuits:

Our missionaries know through constant experiences to their greatest regret that where the erroneous Islamic faith has established itself Christianity cannot develop or cannot be maintained if it is introduced there. But at other locations where the Koran is either unknown or rejected altogether, the true faith will ultimately vanquish the superstition. As we can learn from this, the Islamic sect has not only really spread, but increases on a daily basis in Tartary, in the entire Mongolian empire and in China, in Madura [near Indonesia], Malabria [India], Pegu [Myanmar], Siam [Thailand], Malacca [Malaysa], Java, the Philippines, indeed in all Oriental countries. ${ }^{24}$

24 “Massen aber unsere Missionarii durch beständige Erfahrnuß zu ihrem grösten Leid gäntzlich überwisen seynd / daß wo der Mahometanische Fabel=Glaub einmal einnistet / daselbst das Christenthum entweders nicht aufkommen könnte oder wenn es auch aufkommt, keinen Bestand habe: in andern Orten hingegen / wo der Alcoran entweders unbekant ist oder gäntzlich verworffen wirdt / der wahre Glaub über die Abgötterey endlich obsige; als folget hieraus / daß weil die Mahometanische Sect sich nicht allein in die Tartarey / in das gantze Mogorische Kayserthum und in China, sondern auch Maduram, Malabriam, Pegu, Siam, Malaccam, Javam, wie auch in die Philippinische 
Of course, Stöcklein, like most other missionaries and colonialists, was deeply Eurocentric, and regarded the natives in America and elsewhere like small children who desperately needed their education from the Jesuits (XXX 1r). In fact, that might well have been one of the pervasive attitudes determining the Jesuits at large (and virtually all other Christian missionaries), who felt obliged to help the natives as fathers would educate their children. They were, hence, deliberately patronizing the members of their new parishes all over the world, but this was their self-identified mission, their religious calling, and their personal dedication, helping to bring the Christian faith to the heathens globally.

European readers were invited to see the entire world as within their reach. They could read material rich with Jesuit missionizing, struggling, working, and suffering in every corner of the Earth. Under Jesuit leadership, human history had finally assumed a global perspective, since Christianizing even those people furthest away from Europe was an imperative every Jesuit was supposed to embrace whole-heartedly. China, South America, North America, or India were no longer mysterious names, but concrete locations where Jesuits had gone and where they had accomplished heroic deeds. In this regard, Ethiopia was as important as the Philippines. China mattered as much as Mexico and Pimería Alta, too. The maps Stöcklein included pointed the way for his readers to follow Jesuit models and to continue the missionaries' ideals. Of course, in this hefty volume, readers were also invited to explore the wide world both theoretically and practically. Ceylon, as it was called then (today, Sri Lanka) was no longer simply an exotic place, and Formosa (today, Taiwan) could be visited as well. Even the remote Sonoran Desert emerged as an important link in the Jesuits' global network. They wrote, of course, primarily about their religious interests and concerns, but the Jesuits also wrote invaluable documents comprising the first anthropological, natural, geological, climatological, economic, and political studies in many different parts of this world.

To conclude, the history of the Jesuits in a global context contains valuable lessons and exposes possible fallacies in common historiography. First, globalization began earlier than in the nineteenth century. Second, the Jesuits represented, in a way, the characteristic world citizen of their time. Third, a component which was touched on only briefly in this overview, many of them experienced a very hard life, working tirelessly and devoutly in very remote missions in many different parts of the world. They had abandoned comfortable teaching and research positions back home in the German-speaking world; they traveled across the oceans to reach distant and unfamiliar lands; 
they were forced to learn different languages; they also faced much opposition, if not open hostility, from many sides. Their true and full suffering, however, only came in 1767 when they were all expelled from the Americas and when the Order was banned altogether globally in 1773. Thousands of them were forced from their missions, herded back to central locations, then shipped across the Atlantic Ocean, and subsequently lingered in monastic prisons in Spain for years to come.

Many of them died on the way, and all of them suffered badly, as Joseph Och, for instance, reported in great detail. ${ }^{25}$ With the suppression of the Jesuits, a global organization was quickly destroyed, since there was not much which they could do to defend themselves, because they had been trained to obey their superiors. Some of them, such as Ignaz Pfefferkorn, later turned to writing and published extensive reports about their experiences. ${ }^{26}$ But their documents have hardly attracted much attention, except among anthropologists and historians of the Southwest of the United States. Most texts have never been reprinted, such as the Welt-Bott, even though the Jesuits were present in many parts of the world and deeply influenced the local cultures through their missionary activities.

If we are truly interested in writing 'global history' and look for practical cases to illustrate what this might mean, and if we the past to be heard again since it can tell us much about human suffering, resilience, and triumphs, then the history of the Jesuits, both in America and elsewhere, offers itself almost by itself for close examination. Their rise since the foundation and official establishment in 1540 to their heyday in the middle of the eighteenth century came to a sudden and tragic end in 1767 and 1773 . While the history of the Philippines and Tawain, for instance, and the history of Europe were closely connected at that time via the Jesuits, the subsequent centuries witnessed very different conditions. Colonialism replaced Jesuit missions, and the memory of this global order quickly faded.

Despite its fairly robust recovery since 1814, the Jesuit Order has not fared well in public memory, although it continues to be present in many parts of the world and operates quite impressively. Both the Protestant propaganda campaign against the Jesuits and many internal and external problems in Europe associated with the Order, achieved their effect, and the common understanding of the history of the New World and many other countries all over the

${ }_{25}$ J. Och, Nachrichten von verschiedenen Ländern des Spanischen Amerika, ed. Ch. Gottlieb von Murr, p. 2, Halle 1809.

${ }^{26}$ I. Pfefferkorn, Beschreibung der Landschaft Sonora samt andern merkwürdigen Nachrichten von den inneren Theilen Neu=Spaniens und Reise aus Amerika bis in Deutschland, vol. 2, Cologne 1795 [reprint: ed. I. Schröder, Beiträge zur Forschungsgeschichte, Bonn 1996]. 
globe was deeply reconfigured, specifically to the disadvantage of the Jesuits. Fortunately, we currently witness a kind of Renaissance regarding the history and culture of that Order, and if we recognize in it a precursor of contemporary efforts of globalization with all its positive and negative implications, we find ourselves in an excellent situation of recovering long-lost memory and opening our perspectives toward world history in a most meaningful and practical way. As the example of the Jesuit missionaries in the Sonoran desert demonstrates, even the history of this remote outpost proves to be relevant and insightful for global history, since those missions were essential parts of the huge Jesuit network spanning the entire world.

This is not to glorify their missionary work uncritically. They faced, of course, enormous difficulties both with the native population and the Spaniards/Mexicans. There were a lot of misunderstandings in cultural and religious terms, but generally, the Jesuits made amazing efforts to create this global system of missions in order to preach to the natives, convert and baptize them, and thus to expand universally the Christian faith. They brought with them countless European inventions, ideas, concepts, and materials, so they were certainly at the vanguard of a massive innovation in the Americas and in many other parts of the world. Naturally, their European perspective could perhaps even be classified as 'imperialist' today, but in the context of the eighteenth century we can only acknowledge their astoundingly selfless and passionate work dedicated to their missionary goals.

\section{SUMMARY}

One of the most successful missionary organization, the Jesuits, also operated in northern Mexico in the area today identified as the Sonoran Desert, comprising the Mexican state of Sonora and the US state of Arizona. By the early eighteenth century increasingly German-speaking missionaries arrived and worked hard in the wide network of missions originally established by the pioneer Padre Eusebio Kino (d. 1711) to spread God's words. They also worked intensively on studying that territory and produced numerous written records about their experiences, their research, and the conditions of that world. They were expelled in 1767 and banned globally in 1783, but until then they achieved greatest success with the native population. Their missionary accounts prove to be highly exiting historical, anthropological, religious, and scientific documents most important for missionary history.

Keywords: Memory, Jesuits, Global Network, Missionaries in the New World, Mexico, Sonora, Arizona, globalization, missionizing, Eusebio Kino, Joseph Stoecklein, Welt-Bott, Ignaz Pfefferkorn, Philipp Segesser 
Słowa kluczowe: pamięć, sieć globalna, jezuici, misjonarze w Nowym Świecie, Meksyk, Sonora, Arizona, globalizacja, misjonizacja, Eusebio Kino, Joseph Stoecklein, Welt-Bott, Ignaz Pfefferkorn, Philipp Segesser

\section{BIBLIOGRAPHY}

Allgemeine deutsche Biographie (in print and online at: http://www.deutsche-biographie.de/index. html)

Allerhand So Lehr-als Geist-reiche Brief / Schrifften und Reis-Beschreibungen / Welche von denen Missionariis der Gesellschafft Jesu Aus Beyden Indien / und andern Über Meer gelegenen Laendern / Seit An. 1642. biß auf das Jahr 1726 in Europa angelangt seynd. Jetzt zum erstenmal Theils aus Handschrifftlichen Urkunden / theils aus denen Französischen Lettres Edifiantes verteutscht und zusammen getragen, von Joseph Stöcklein (Fortgesetzt von Petrus Probst und Franciscus Keller), Augsburg-Graz: In Verlag Philips / Martins / und Joh. Veith seel. Erben, 1725-1758. [All Kinds of Instructive and Intelligent Letters, Tracts, and Travelogues Which Had Been Written and sent to Europe by Missionaries of the Society of Jesus in Both Indies and in Other Countries Situated Overseas from 1642 to 1726; Now for the First Time Translated and Compiled to Some Extent From Handwritten Documents, to Another Extent from the French Lettres Edifiantes].

Classen A., Early History of the Southwest Through the Eyes of German-Speaking Jesuit Missionaries: A Transcultural Experience in the Eighteenth Century, Lanham, Boulder, et al.: Lexington Books, 2013.

Classen A., España a través del prisma alemán: perspectivas del Medievo y la primera Modernidad e investigaciones imagológicas, in: Viajes y viajeros entre ficción y realidad: AlemaniaEspaña, ed. B. Raposo Fernández, I. García Wistädt, Valencia: Universitat de València, 2009, p. 41-59.

Classen A., The Letters of the Swiss Jesuit Missionary Philipp Segesser (1689-1762): An Eyewitness to the Settlement of Eighteenth-Century Sonora (Pimeria Alta), ed. and trans. A. Classen, [Arizona Center for Medieval and Renaissance Studies, Occasional Series, 5], Tempe: Arizona Center for Medieval and Renaissance Studies, 2012.

Classen A., The Scientific, Anthropological, Geological, and Geographic Exploration of Northern Mexico by Eighteenth-Century German Jesuit Missionaries: A Religious and Scientific Network of Multilingual Writers. With a Focus on Johann Nentuig and Marcus Antonius Kappus, "Mitteilungen des Instituts für Österreichische Geschichtsforschung” 122.1 (2014), p. 40-61.

Conwell J.F., SJ, Impelling Spirit: Revisiting a Founding Experience: 1539. Ignatius of Loyola and His Companions, Chicago: Loyola Press, 1997.

Deutsche Jesuitenmissionäre des 17. und 18. Jahrhunderts: Ein Beitrag zur Missionsgeschichte und zur deutschen Biographie, [Ergänzungshefte zu den "Stimmen aus Maria-Laach," 74], Freiburg i. Br.: Herder, 1899.

Duhr B., SJ, Deutsche Auslandssehnsucht im 18. Jahrhundert: Aus der überseeischen Missionsarbeit deutscher Jesuiten [Schriften des Deutschen Auslands-Instituts. A: Kulturhistorische Reihe, 20], Stuttgart: Ausland und Heimat, 1928.

El saber de los jesuitas: historias naturales y el Nuevo Mundo, ed. L. Millones Figueroa, D. Ledezma, [Textos y estudios coloniales y de la independencia, 12], Frankfurt a. M.: Vervuert; Madrid: Iberoamericana, 2005.

Haley J.L., Apaches: A History and Culture Portrait, Norman, OK: University of Oklahoma Press, 1997. Haub R., Die Geschichte der Jesuiten, Darmstadt: Wissenschaftliche Buchgesellschaft, 2007.

Hausberger B., Für Gott und König: die Mission der Jesuiten im kolonialen Mexiko, [Studien zur Geschichte und Kultur der iberischen und iberoamerikanischen Länder, 6], Vienna: Verlag für Geschichte und Politik; Munich: R. Oldenbourg, 2000. 
Hausberger B., Jesuiten aus Mitteleuropa im kolonialen Mexiko: Eine bio-bibliographie, Vienna:

Verlag für Geschichte und Politik; Munich: R. Oldenbourg Verlag, 1995.

http://epicworldhistory.blogspot.com/2012/06/franciscans-in-americas.html [online 20.10.2014].

http://www.jesuit.org.au/files/docs/our-community/our-story/the-history-of-the-jesuits-in-australia. pdf [online 20.10.2014].

Ignatianisch: Eigenart und Methode der Gesellschaft Jesu, ed. M. Sievernich, SJ, G. Switek, SJ, Freiburg i.Br.-Basel-Vienna: Herder, 1990.

Jesuitische Musik- und Theaterpraxis im kolonialen Amerika, ed. Ch. Storch (forthcoming).

Lacouture J., Jesuits: A Multibiography, Washington, DC: Counterpoint, 1995.

Letson D., Higgins M., The Jesuit Mystique, Toronto: Macmillan, 1995.

Mitchell D., The Jesuits: A History, London: Macdonald Futura Publishers, 1980.

Och J., Nachrichten von verschiedenen Ländern des Spanischen Amerika, ed. Ch. Gottlieb von Murr, p. 2, Halle: Joh. Christian Hendel, 1809.

Ortega Urquidi J., Apaches del Desierto, Mexico City: Impresora Pena Santa, 2011.

Paintner U., 'Des Papsts neue Creatur': Antijesuitische Publizistik im deutschsprachigen Raum (1555-1618), [Chloe, Beihefte zum Daphnis, 44], Amsterdam-New York: Editions Rodopi, 2011.

Pfefferkorn I., Beschreibung der Landschaft Sonora samt andern merkwürdigen Nachrichten von den inneren Theilen Neu=Spaniens und Reise aus Amerika bis in Deutschland, vol. 2, Cologne: Langenscheu Buchhandlung, 1795 [reprint: ed. I. Schröder, Beiträge zur Forschungsgeschichte, Bonn: Holos, 1996].

Polzer Ch.W., SJ, Kino: A Legacy. His Life, His Works, His Missions, His Monuments, Tucson, AZ: Jesuit Fathers of Southern Arizona, 1998.

Reff D.T., Plagues, Priests, and Demons: Sacred Narratives and the Rise of Christianity in the Old World and the New, Cambridge-New York: Cambridge University Press, 2005.

Schmuck H., Philipp Segesser, SJ (1689-1762): Exemplarische Biographie eines mitteleuropäischen Missionars in Nueva España, [Mainzer Studien zur Neueren Geschichte 11], Frankfurt a. M.: Peter Lang, 2004.

Schroth R.A., SJ, The American Jesuits: A History, New York-London: New York University Press, 2007.

Stark R., How the West Won: The Neglected Story of the Triumph of Modernity, Wilmington, DE: ISI Books, 2014.

The Mercurian Project: Forming Jesuit Culture 1573-1580, ed. Th.M. McCoog, SJ, [Biblioteca Instituti Historici Societatis Jesu, 55], St. Louis, MO, and Rome-Prati: The Institute of Jesuit Sources, 2004.

Worcester D.E., The Apaches: Eagles of the Southwest, [Civilization of the American Indian Series, 149], Norman, OK: University of Oklahoma Press, 1979.

Dr Albrecht Classen - University Distinguished Professor and Undergraduate Advisor in the Department of German Studies, University of Arizona. His recent publications include: Handbook of Medieval Studies, ed. Albrecht Classen, 3 vols., Berlin and New York: De Gruyter, 2010; Early History of the Southwest Through the Eyes of German-Speaking Jesuit Missionaries: A Transcultural Experience in the Eighteenth Century, Lanham, MD: Lexington Books, 2013; Love, Lust, and Life: The Verse Narratives by Heinrich Kaufringer, Tempe, AZ: ACMRS, 2014. 